\title{
MicroRNAs as molecular markers in lung cancer
}

\author{
Javier Silva1, Vanesa Garcia1, Ana Lopez-Gonzalez², Mariano Provencio ${ }^{1}$ \\ ${ }^{1}$ Medical Oncology Department, Hospital Universitario Puerta de Hierro, Majadahonda-Madrid, Spain \\ ${ }^{2}$ Medical Oncology Department, Complejo Asistencial Universitario de León, Spain
}

Received September 04, 2013; Revised October 04, 2013; Accepted October 07, 2013; Published Online October 10, 2013

\section{Review Article}

\begin{abstract}
Lung cancer is the most common cause of cancer death in the western world for both men and women. Lung cancer appears to be a perfect candidate for a screening program, since it is the number one cancer killer, it has a long preclinical phase, curative treatment for the minority of patients who are diagnosed early and a target population at risk (smokers) and it is also a major economic burden. The earliest approaches to identifying cancer markers were based on preliminary clinical or pathological observations, although molecular biology is a strong candidate for occupying a place among the set of methods. In search of markers, several alterations, such as mutations, loss of heterozygosity, microsatellite instability, DNA methylation, mitochondrial DNA mutations, viral DNA, modified expression of mRNA, miRNA and proteins, and structurally altered proteins have all been analysed. MicroRNAs (miRNA) are small RNA molecules, about 19-25 nucleotides long and encoded in genomes of plants, animals, fungi and viruses. It has been reported that miRNAs may have multiple functions in lung development and that aberrant expression of miRNAs could induce lung tumorigenesis. We review here the role of miRNAs in lung tumorigenesis and also as a novel type of biomarker.
\end{abstract}

Keywords: Lung Cancer, MicroRNA, Biomarker, Tumorigenesis

\section{Introduction}

Lung cancer is the most common cause of cancer death in the western world for both men and women. ${ }^{1}$ Each year the number of lung cancer deaths is greater than the number of deaths from breast, prostate and colorectal cancer combined. ${ }^{2}$ In 2007, estimates calculated 213,380 new cases of lung cancer and 160,390 deaths, accounting for $15 \%$ and $29 \%$, respectively, of all cases of cancer. ${ }^{2}$ Clinically, lung cancer can be divided into 2 groups: small cell lung cancer (SCLC) and non-small cell lung cancer (NSCLC), which often have different specific genetic alterations. ${ }^{3}$ Approximately $75 \%$ of lung tumours are NSCLC, which includes squamous cell carcinoma, adenocarcinoma and large cell

Corresponding author: Mariano Provencio, MD, PhD; Medical Oncology Department, Calle Manuel de Falla, 1 Majadahonda, Madrid 28222, Spain.

Email: mprovenciop@gmail.com

Cite this article as: Silva J, Garcia V, Lopez-Gonzalez A, Provencio M. MicroRNAs as molecular markers in lung cancer.Int J Cancer Ther Oncol 2013;1(1):010111. DOI: 10.14319/ijcto.0101.11 carcinoma. ${ }^{1}$ SCLC is characterized by its rapid growth, early dissemination and chemosensitivity andradiosensitivity. ${ }^{4}$

Over $80 \%$ of lung cancers are attributable to cigarette smoking $^{5}$, with a risk directly proportional to consumption. Thus, cessation of smoking remains the single most important intervention for lung cancer prevention: recently some progress has been made by the introduction of smoking bans in public places throughout Europe. Although the exposure to tobacco carcinogens is known to be the main risk factor for lung cancer, only a minority of heavy smokers will develop this disease ${ }^{6}$, suggesting environmental or genetic determinants in disease initiation and progression. Thus, inter-individual differences in carcinogen metabolism may play an essential role in the development of this environmental cancer. ${ }^{7}$ In addition, with the increasing incidence of non-smoking-related lung cancers, particularly in women, the identification of high-risk groups among non-smokers will be an important challenge. ${ }^{8}$

Whereas screening the general population has been recommended for other common cancers, including breast, colorectal and possibly prostate cancer, no such recommendation currently exists for lung cancer. ${ }^{9}$ Only between $10-16 \%$ of lung cancer patients survive more than 5 years. ${ }^{2}$ The dismal 
prognosis of lung cancer is largely related to the fact that this tumour is generally diagnosed at a late stage. However, outcome is significantly better in patients diagnosed early, with the 5-year survival rate of stage 1 lung cancer at $60-70 \%{ }^{10}$ Early detection of lung cancer could change disease outcome, although current diagnostic tools are either too costly or not sensitive enough to allow early detection. ${ }^{11,12}$ For all these reasons, it is essential to develop an effective screening regimen for this disease.

Lung cancer appears to be a perfect candidate for a screening program, since it is the number one cancer killer, it has a long preclinical phase, curative treatment for the minority of patients who are diagnosed early and a target population at risk (smokers) and it is also a major economic burden.

\section{Molecular markers}

The progression from pre-neoplasia to cancer is accompanied by the accumulation of genetic and epigenetic alterations. These lead to altered expression patterns and modifications in protein structure and function. The changes can be used as molecular tumour markers, being useful in: a) characterization of a predisposition or genetic susceptibility to suffering neoplasia; b) detection of cancer at early stages or pre-malignant phases; c) the evaluation of disease outcome; d) monitoring of disease progression; and e) determination of response to therapy, so favouring a better choice of therapy for each patient.

Currently, the diagnostic tools for lung carcinoma are: chest $\mathrm{X}$-ray, computed tomography (CT), cytological analysis of sputum and bronchoalveolar lavage fluid, and spiral CT, among others. However, to develop more strategies, diagnosis, prognosis and treatment need to be improved. The goal of clinical and potential molecular markers is to develop a clinical screening test that would be useful and practical in clinical practice, complementing the use of imaging modalities such as spiral CT.

The earliest approaches to identifying cancer markers were based on preliminary clinical or pathological observations ${ }^{13}$, although molecular biology is a strong candidate for occupying a place among the set of methods. In search of markers, several alterations, such as mutations, loss of heterozygosity, microsatellite instability, DNA methylation, mitochondrial DNA mutations, viral DNA, modified expression of mRNA, miRNA and proteins, and structurally altered proteins have all been analyzed. High-throughput screening approaches that analyze expression patterns of several genes and proteins have been used to search for cancer-associated molecules. ${ }^{13}$ In lung carcinomas several alterations have been found, such as KRAS mutated in approximately 30\% of cases $^{14}$, over-expression of $C$-erbB2 (Her-2/neu) or BCL2 in $25 \%$ of cases $^{14}$ and $D L C 1$ (deleted in lung cancer 1 ) altered in $27 \%$ of primary NSCLC. ${ }^{15}$
In clinical practice, there are several molecular tumour markers used for screening in some tumour types, such as serum carcino-embryonic antigen (CEA) in colorectal cancer $^{16}$ and prostate-specific antigen (PSA) in prostate cancer. ${ }^{17}$ However, these markers are not very sensitive in premalignant or early stages or are not specific to malignancy. For most other types of cancer, such as early-stage lung cancer, there are no molecular markers available in clinical practice.

Although many effective cancer therapies have recently been developed, there are only a few molecular markers that are available at present for determining treatment response. For example, breast cancer cells that express high levels of the tyrosine receptor kinase are more likely to respond to trastuzumab. ${ }^{18}$ In lung cancer, the ability to predict responses to chemotherapy or targeted agents is extremely limited and is based on tumour histology alone. Therefore, we are unable to identify a priori the right treatment regimen for each tumour. Appropriate molecular markers could predict response to specific treatments. An example is the use of epithelial growth factor tyrosine kinase inhibitors (EGFR-TKIs) in lung cancer. ${ }^{19}$ Although more studies are necessary, it has been described that a series of mutations in EGFR makes tumours highly sensitive to this form of therapy. Thus, detection of these mutations could identify a group of patients who derive great benefit from EGFR-TKI therapy. ${ }^{19}$ Another example is the use of molecular markers in relation to cisplatin treatment. Only a proportion of lung cancer patients will respond to this chemotherapy treatment, whose adverse side-effects are significant. Cisplatin needs to bind to DNA, creating platinum-DNA adducts, which can be repaired by nucleotide excision. Patients with completely resected NSCLC and ERCC1-negative tumours (enzyme with central role in DNA repair) appear to benefit from adjuvant cisplatin-based chemotherapy, whereas patients with ERCC1-positive tumours do not. ${ }^{20}$

\section{microRNAs as molecular markers}

MicroRNAs (miRNA) are small RNA molecules, about 19-25 nucleotides long and encoded in genomes of plants, animals, fungi and viruses.

miRNAs constitute a highly conserved class of naturally occurring non-coding single-stranded RNA molecules, which function as post-transcriptional negative gene regulators of complementary target mRNAs. Although they may differ in distinct organisms, the basic process involves a transcription of dsRNA that is processed into shorter units that mediate target recognition in a sequence-specific manner (Table 1). ${ }^{21}$ It has been calculated that between $74 \%$ and $92 \%$ of the gene transcripts are probably under miRNA control. ${ }^{22,23}$ 
TABLE 1:Main Studies that have investigated miRNA in lung cancer

\begin{tabular}{l}
\hline \hline Yanaihara et al. Cancer Cell. 2006 \\
Lu et al. Proc Am Thorac Soc. 2008 \\
Fabbri et al. Proc Natl Acad Sci. 2007 \\
Inamura et al. Lung Cancer. 2007 \\
Yu et al. Cancer Cell. 2008 \\
Fagi F. Thorac Surg Clin. 2012 \\
Rabinowits et al. Clin Lung Cancer. 2009 \\
Hu et al. J Clin Oncol. 2010 \\
Hennessey et al. PLoS One. 2012 \\
Bianchi et al. E cancer medical science. 2012 \\
Matsubara et al. Oncogene. 2007 \\
Shen et al. Lab Invest. 2011 \\
Rani et al. Cancer Biol. Ther. 2013 \\
Xu et al. Clin Transl Oncol. 2013 \\
Zhang et al. Med Oncol. 2013 \\
\hline \hline
\end{tabular}

miRNAs are specifically expressed or greatly enriched in a particular organ, implying an organ- or tissue-specific function. Furthermore, expression profiles of miRNAs in mice and human lung are very similar, indicating evolutionary conservation of miRNA expression. ${ }^{24,25}$ It has been reported that lung is one of the tissues with the most abundant expression of miRNA let-7.26

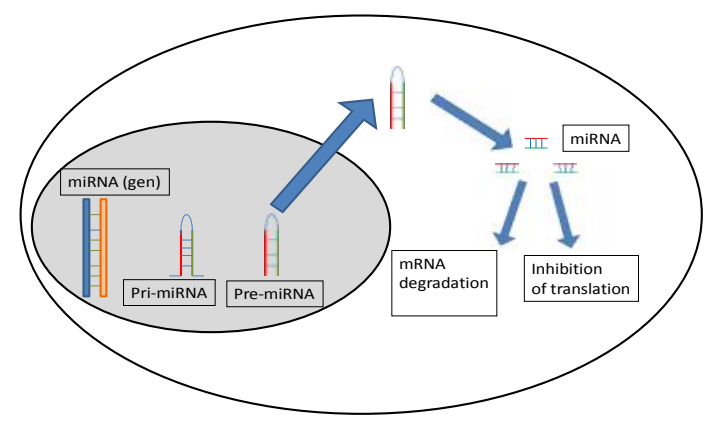

FIG. 1: miRNA function

There are several human diseases, such as spinal muscular atrophy, Parkinson's disease, fragile X mental retardation or DiGeorge syndrome, in which miRNAs or their processing might be involved. $27-29$ Among human diseases, it is well-known that miRNAs are aberrantly expressed in numerous human cancers, including colon, breast, ovarian, prostate and lung cancer ${ }^{30,31}$ (Figure 1). Moreover, since a single miRNA may have as many as a few thousand target genes with different biological entities, the data obtained from miRNA profiling may provide information that can be used to classify more accurately the different cancer subtypes described to date. Besides regulating the expression of known oncogenes and tumour suppressors, miRNAs also act as oncogenes and tumour suppressors directly, which provides an apparent connection between the altered expression of miRNAs and cancer development. Thus, miRNA-expression profile of human tumours is closely associated with diagnosis, staging, progression, prognosis and response to treatment. ${ }^{31-33}$
In the case of lung cancer, it has been reported that miRNAs may have multiple functions in lung development and that aberrant expression of miRNAs could induce lung tumorigenesis. ${ }^{34,35}$ Moreover, as mentioned above, the different expression profiles of miRNAs between normal lung and lung cancer has led to their emergence as a novel type of biomarker. This may be helpful for lung cancer diagnosis and therapy using miRNAs as novel therapeutic targets. 36,37

The current diagnostic tools available for lung cancer often lack sensitivity and the ability to distinguish different lung cancer subtypes, such as NSCLC and SCLC or adenocarcinoma and squamous cell carcinoma. ${ }^{38,39}$ In this respect, the applicability of miRNA-based biomarkers may improve methodology for both sensitivity and specificity. Differently expressed miR-29 (a, b and c), miR-99b, miR-102, let-7a-2 and let-7f-1 have been used to discriminate histological types of lung carcinomas. ${ }^{32,40}$ As well as data strongly supporting the view that miRNAs work as biomarkers for differentiating lung cancer, the expression of miRNA signatures has been linked to the prognosis of lung cancer. Deregulated expression of the let-7 family has been frequently described in different analyses of miRNA expression signatures in lung cancer. The decrease in the let-7 family is associated with worse prognosis and shortened survival, which supports the view that it has a tumour suppression function. ${ }^{41-43}$ Deregulated miRNA has been also related with lymph node metastasis and advanced clinical stage. ${ }^{44}$

Talking about EGFR-TKIs, we know that patients with activating EGFR mutations eventually develop resistance to this drugs. It is thought that a secondary mutation in the EGFR gene, such as T790M, or amplification of the MET proto-oncogene could be implicated. Recently, upregulated $\mathrm{miR}-214$ has been related to acquired resistance to gefitinib, via PTEN/AKT signalling pathway. ${ }^{45}$

\section{MicroRNAs in plasma from cancer pa- tients}

The presence in plasma or serum of circulating nucleic acids (DNA and RNA) released by tumour cells increases the possibility of detecting alterations associated with the tumour and could be used as a tumour marker. Furthermore, as circulating nucleic acids are a source of tumour information obtained through a non-invasive and rapid method, samples could be taken at different times during follow-up to identify residual disease and recurrence at asymptomatic stages.

MiRNAs originating in several tumour tissues enter circulation and can be detected in serum. The fact that plasma contains large amounts of stable miRNAs implies a great potential of serum miRNA profiling as the fingerprint for disease. ${ }^{46}$ Regarding the release mechanism of nucleic acids from tumour cells to the bloodstream, we recently reported that a major fraction of these molecules detected in plasma of can- 
cer patients are highly protected in tumour-specific microvesicle-like structures. ${ }^{47}$ In other studies, cancer-specific miRNAs with high resistance to RNases and harsh conditions were identified in plasma or serum of cancer patients ${ }^{46,48-52}$ showing that the high stability conferred by its particle-associated features makes miRNA levels well suited for being tested as non-invasive cancer biomarkers in patient plasma samples. Moreover, other studies have suggested that miRNAs contained in tumour vesicles are functional and suppress target mRNAs for signal transduction components within recipient cells. ${ }^{53}$

Recently, our group as well as other research groups have analysed serum miRNA profiles of lung cancer patients to evaluate their potential use in predicting diagnosis and prognosis of disease.46, 54, 55 Employing Solexa sequencing analysis, the Chen et al. ${ }^{46}$ identified specific expression patterns of serum miRNAs for lung cancer in the Chinese population. They provided evidence that serum miRNAs contained fingerprints for different cancer types. Most differently expressed miRNAS in lung cancer included miR-205 and miR-206 that were previously involved in tumorigenic processes such as cell division and cell growth. Similarly, Lodes et al. focused their study on the evaluation of miRNA expression profiles in human serum for five types of human tumours, including lung cancer, using a pan-human microRNA high-density microarray. They found that these expression patterns could be used to distinguish between normal and cancer patient samples and, furthermore, that one millilitre of serum contained sufficient miRNAs to detect these expression patterns, without requiring amplification techniques. In a recent study, Hu's group analyzed the differences in levels of serum miRNAs between 30 NSCLC patients with longer survival and 30 patients with shorter survival. Using Solexa sequencing, they found 11 differently altered miRNAs between longer-survival and shorter-survival groups and, moreover, levels of 4 of them (miR-1, miR-30d, miR-486 and miR499) were significantly associated with overall survival.

Recently, a phase I//II biomarker study has been published, in which serum miRNA using PCR was examined from 30 NSCLC patients and 20 healthy controls. A combination of two differentially expressed miRNAs miR-15b and miR-27b was able to discriminate NSCLC from healthy controls. ${ }^{56}$

Combining serum mi-RNA detection and low-dose computed tomography (LD-CT) could be an interesting screening test. Real-time PCR was used to identify the profile of miRNAs extracted from the serum of asymptomatic LD-CT-detected lung adenocarcinoma and normal serum. A multivariate risk-predictor was developed based on 34 miRNA expression levels. When the predictor was tested on an independent cohort of patients with asymptomatic LD-CT detected lung cancer, it displayed an overall accuracy of $80 \%$ (sensitivity $71 \%$, specificity $90 \%$ ), and more important, the risk-predictor was able to distinguish between
LD-CT-detected benign nodules and malignant disease. ${ }^{57} \mathrm{We}$ agree with the relevance of this last point, due to the relative high number of benign lung nodules detected by LD-CT screening.

\section{Conclusion}

miRNAs are frequently altered in many types of tumours, including lung carcinoma. Their expression patterns are associated with the classification and prognosis of these tumours. That miRNAs are stable in plasma from lung cancer patients supports their use as important clinical biomarkers ${ }^{58}$, 59,60 detectable in peripheral blood associated with tumour.

The fact that certain miRNAs have an oncogenic function while others have a role as tumour suppressors is especially relevant in terms of their applicability in anti-tumour therapies. Thus, oncogenic miRNAs would require therapies inhibiting their function, while those therapies for miRNAs with tumour suppressor ability should increase miRNA activity in cancer cells. There are some studies that analyze the potential of miRNA-based therapies in cancer. ${ }^{61,62}$

In summary, the expression of miRNA signatures in plasma from lung cancer patients can be used as new markers, obtained by a non-invasive method, for disease diagnosis and prognosis. They have higher specificity and sensitivity than analyses used currently.

\section{References}

1. Risch A, Plass C. Lung cancer epigenetics and genetics. Int J Cancer 2008; 123: 1-7.

2. Jemal A, Siegel R, Ward E, Hao Y, Xu J, Murray T, Thun MJ. Cancer statistics. CA Cancer J Clin 2008; 58:71-96.

3. Girard L, Zöchbauer-Müller S, Virmani AK, Gazdar AF, Minna JD. Genome-wide allelotyping of lung cancer identifies new regions of allelic loss, differences between small cell lung cancer and on-small cell lung cancer, and loci clustering. Cancer Res 2000; 60:4894-906.

4. Cooper S, Spiro SG. Small cell lung cancer: treatment review. Respirology 2006; 11: 241-8.

5. Khuder SA. Effect of cigarette smoking on major histological types of lung cancer: a meta-analysis. Lung Cancer 2001; 31:139-48.

6. Mattson ME, Pollack ES, Cullen JW. What are the odds that smoking will kill you? Am J Public Health 1987; 77:425-31. 
7. Schwartz AG, Prysak GM, Bock CH, Cote ML. The molecular epidemiology of lung cancer. Carcinogenesis 2007; 28:507-18.

8. Wakelee HA, Chang ET, Gomez SL, Keegan TH, Feskanich D, Clarke CA, Holmberg L, Yong LC, Kolonel LN, Gould MK, West DW. Lung cancer incidence in never smokers. J Clin Oncol 2007; 25:472-8.

9. Smith RA, Cokkinides V, Eyre HJ. Cancer screening in the United States, 2007: a review of current guidelines, practices, and prospects. $C A$ Cancer $J$ Clin 2007, 57:90-104.

10. Spira A, Ettinger DS. Multidisciplinary management of lung cancer. $N$ Engl J Med 2004; 350:379-92.

11. International Early Lung Cancer Action Program Investigators, Henschke CI, Yankelevitz DF, Libby DM, Pasmantier MW, Smith JP, Miettinen OS. Survival of patients with stage I lung cancer detected on CT screening. $N$ Engl J Med 2006; 355:1763-71.

12. Markowitz SB, Miller A, Miller J, Manowitz A, Kieding S, Sider L, Morabia A. Ability of low-dose helical CT to distinguish between benign and malignant noncalcified lung nodules. Chest 2007; 131:1028-34.

13. Sidransky D. Emerging molecular markers of cancer. Nat Rev Cancer 2002; 2:210-9.

14. Salgia R, Skarin AT. Molecular abnormalities in lung cancer. JClin Oncol 1998; 16:1207-17.

15. Daigo $Y$, Nishiwaki T, Kawasoe T, Tamari M, Tsuchiya E, Nakamura Y. Molecular cloning of a candidate tumor suppressor gene, DLC1, from chromosome 3p21.3. Cancer Res 1999; 59:1966-72.

16. Benson AB 3rd, Choti MA, Cohen AM, Doroshow JH, Fuchs C, Kiel K, Martin EW Jr, McGinn C, Petrelli NJ, Posey JA, Skibber JM, Venook A, Yeatman TJ; National Comprehensive Cancer Network. NCCN Practice Guidelines for Colorectal Cancer. Oncology (Williston Park) 2000; 14:203-12.

17. Feneley MR, Partin AW. Diagnosis of localized prostate cancer: 10 years of progress. Curr Opin Urol 2000; 10:319-27.

18. Harris LN, Liotcheva V, Broadwater G, Ramirez MJ, Maimonis P, Anderson S, Everett T, Harpole D, Moore MB, Berry DA, Rizzeri D, Vredenburgh JJ,
Bentley RC. Comparison of methods of measuring HER-2 in metastatic breast cancer patients treated with high-dose chemotherapy. J Clin Oncol 2001; 19:1698-706.

19. Rosell R, Morán T, Carcereny E, Quiroga V, Molina MA, Costa C, Benlloch S, Tarón M. Non-small-cell lung cancer harbouring mutations in the EGFR kinase domain. Clin Transl Oncol 2010; 12:75-80.

20. Olaussen KA, Dunant A, Fouret P, Brambilla E, André F, Haddad V, Taranchon E, Filipits M, Pirker R, Popper HH, Stahel R, Sabatier L, Pignon JP, Tursz T, Le Chevalier T, Soria JC; IALT Bio Investigators. DNA repair by ERCC1 in non-small-cell lung cancer and cisplatin-based adjuvant chemotherapy. $N$ Engl J Med 2006; 355:983-91.

21. Matzke M, Matzke AJ, Kooter JM. RNA: guiding gene silencing. Science 2001; 293:1080-3.

22. Ambros V. The functions of animal microRNAs. Nature 2004; 431:350-5.

23. Bartel DP. MicroRNAs: genomics, biogenesis, mechanism, and function. Cell 2004; 116:281-97.

24. Williams AE, Moschos SA, Perry MM, Barnes PJ, Lindsay MA. Maternally imprinted microRNAs are differentially expressed during mouse and human lung development. Dev Dyn 2007; 236:572-80.

25. Lü J, Qian J, Chen F, Tang X, Li C, Cardoso WV. Differential expression of components of the microRNA machinery during mouse organogenesis. Biochem Biophys Res Commun. 2005; 334:319-23.

26. Pasquinelli AE, Reinhart BJ, Slack F, Martindale MQ Kuroda MI, Maller B, Hayward DC, Ball EE, Degnan B, Müller P, Spring J, Srinivasan A, Fishman M, Finnerty J, Corbo J, Levine M, Leahy P, Davidson E, Ruvkun G. Conservation of the sequence and temporal expression of let-7 heterochronic regulatory RNA. Nature 2000; 408:86-9.

27. Dostie J, Mourelatos Z, Yang M, Sharma A, Dreyfuss G. Numerous microRNPs in neuronal cells containing novel microRNAs. $R N A$ 2003; 9:180-6.

28. Ishizuka A, Siomi MC, Siomi H. A Drosophila fragile $\mathrm{X}$ protein interacts with components of RNAi and ribosomal proteins. Genes Dev 2002; 16:2497-508.

29. Shiohama A, Sasaki T, Noda S, Minoshima S, Shimizu N. Molecular cloning and expression analysis of a novel gene DGCR8 located in the DiGeorge 
syndrome chromosomal region. Biochem Biophys Res Commun 2003; 304:184-90.

30. Esquela-Kerscher A, Slack FJ. Oncomirs - microRNAs with a role in cancer. Nat Rev Cancer 2006; 6:259-69.

31. Calin GA, Croce CM. MicroRNA signatures in human cancers. Nat Rev Cancer 2006; 6:857-66.

32. Yanaihara N, Caplen N, Bowman E, Seike M, Kumamoto K, Yi M, Stephens RM, Okamoto A, Yokota J, Tanaka T, Calin GA, Liu CG, Croce CM, Harris CC. Unique microRNA molecular profiles in lung cancer diagnosis and prognosis. Cancer Cell 2006; 9:189-98.

33. Calin GA, Ferracin M, Cimmino A, Di Leva G, Shimizu M, Wojcik SE, Iorio MV, Visone R, Sever NI, Fabbri M, Iuliano R, Palumbo T, Pichiorri F, Roldo C, Garzon R, Sevignani C, Rassenti L, Alder H, Volinia S, Liu CG, Kipps TJ, Negrini M, Croce CM. A MicroRNA signature associated with prognosis and progression in chronic lymphocytic leukemia. N Engl J Med 2005; 353:1793-801.

34. Lu Y, Okubo T, Rawlins E, Hogan BL. Epithelial progenitor cells of the embryonic lung and the role of microRNAs in their proliferation. Proc Am Thorac Soc 2008; 5:300-4.

35. Johnson CD, Esquela-Kerscher A, Stefani G, Byrom M, Kelnar K, Ovcharenko D, Wilson M, Wang X, Shelton J, Shingara J, Chin L, Brown D, Slack FJ. The let-7 microRNA represses cell proliferation pathways in human cells. Cancer Res 2007; 67:7713-22.

36. Zhang B, Pan X, Cobb GP, Anderson TA. MicroRNAs as oncogenes and tumor suppressors. DeV Biol 2007; 302:1-12.

37. Kent OA, Mendell JT. A small piece in the cancer puzzle: microRNAs as tumor suppressors and oncogenes. Oncogene 2006; 25:6188-96.

38. Field RW, Smith BJ, Platz CE, Robinson RA, Neuberger JS, Brus CP, Lynch CF. Lung cancer histologic type in the surveillance, epidemiology, and end results registry versus independent review. $J$ Natl Cancer Inst 2004; 96:1105-7.

39. Stang A, Pohlabeln H, Müller KM, Jahn I, Giersiepen K, Jöckel KH. Diagnostic agreement in the histopathological evaluation of lung cancer tissue in a population-based case-control study. Lung Cancer 2006; 52:29-36.
40. Fabbri M, Garzon R, Cimmino A, Liu Z, Zanesi N, Callegari E, Liu S, Alder H, Costinean S, Fernandez-Cymering C, Volinia S, Guler G, Morrison CD, Chan KK, Marcucci G, Calin GA, Huebner K, Croce CM. MicroRNA-29 family reverts aberrant methylation in lung cancer by targeting DNA methyltransferases 3A and 3B. Proc Natl Acad Sci USA 2007; 104:15805-10.

41. Takamizawa J, Konishi H, Yanagisawa K, Tomida S, Osada H, Endoh H, Harano T, Yatabe Y, Nagino M, Nimura Y, Mitsudomi T, Takahashi T. Reduced expression of the let-7 microRNAs in human lung cancers in association with shortened postoperative survival. Cancer Res 2004; 64:3753-6.

42. Inamura $\mathrm{K}$, Togashi $\mathrm{Y}$, Nomura $\mathrm{K}$, Ninomiya $\mathrm{H}$, Hiramatsu M, Satoh Y, Okumura S, Nakagawa K, Ishikawa Y. let-7 microRNA expression is reduced in bronchioloalveolar carcinoma, a non-invasive carcinoma, and is not correlated with prognosis. Lung Cancer 2007; 58:392-6.

43. Yu SL, Chen HY, Chang GC, Chen CY, Chen HW, Singh S, Cheng CL, Yu CJ, Lee YC, Chen HS, Su TJ, Chiang CC, Li HN, Hong QS, Su HY, Chen CC, Chen WJ, Liu CC, Chan WK, Chen WJ, Li KC, Chen JJ, Yang PC. MicroRNA signature predicts survival and relapse in lung cancer. Cancer Cell 2008; 13:48-57.

44. Fazi F, Fontemaggi G .MicroRNAs and Lymph Node Metastatic Disease in Lung Cancer. Thorac Surg Clin 2012; 22:167-75.

45. Wang YS, Wang YH, Xia HP, Zhou SW, Schmid-Bindert G, Zhou CC MicroRNA-214 Regulates the Acquired Resistance to Gefitinib via the PTEN/AKT Pathway in EGFR-mutant Cell Lines. Asian Pac J Cancer Prev 2012; 13:255-60.

46. Chen X, Ba Y, Ma L, Cai X, Yin Y, Wang K, Guo J, Zhang Y, Chen J, Guo X, Li Q, Li X, Wang W, Zhang Y, Wang J, Jiang X, Xiang Y, Xu C, Zheng P, Zhang J, Li R, Zhang H, Shang X, Gong T, Ning G, Wang J, Zen K, Zhang J, Zhang CY. Characterization of microRNAs in serum: a novel class of biomarkers for diagnosis of cancer and other diseases. Cell Res 2008; 18:997-1006.

47. García JM, García V, Peña C, Domínguez G, Silva J, Diaz R, Espinosa P, Citores MJ, Collado M, Bonilla F. Extracellular plasma RNA from colon cancer patients is confined in a vesicle-like structure and is mRNA-enriched. RNA 2008; 14:1424-32. 
48. Rabinowits G, Gerçel-Taylor C, Day JM, Taylor DD, Kloecker GH. Exosomal microRNA: a diagnostic marker for lung cancer. Clin Lung Cancer 2009; 10:42-6.

49. Lawrie $\mathrm{CH}, \mathrm{Gal}$ S, Dunlop HM, Pushkaran B, Liggins AP, Pulford K, Banham AH, Pezzella F, Boultwood J, Wainscoat JS, Hatton CS, Harris AL. Detection of elevated levels of tumour-associated microRNAs in serum of patients with diffuse large B-cell lymphoma. Br J Haematol 2008; 141:672-5.

50. Mitchell PS, Parkin RK, Kroh EM, Fritz BR, Wyman SK, Pogosova-Agadjanyan EL, Peterson A, Noteboom J, O'Briant KC, Allen A, Lin DW, Urban N, Drescher CW, Knudsen BS, Stirewalt DL, Gentleman R, Vessella RL, Nelson PS, Martin DB, Tewari M. Circulating microRNAs as stable blood-based markers for cancer detection. Proc Natl Acad Sci U S A 2008; 105:10513-8.

51. Ng EK, Chong WW, Jin H, Lam EK, Shin VY, Yu J, Poon TC, Ng SS, Sung JJ. Differential expression of microRNAs in plasma of patients with colorectal cancer: a potential marker for colorectal cancer screening. Gut 2009; 58:1375-81.

52. Zhu W, Qin W, Atasoy U, Sauter ER. Circulating microRNAs in breast cancer and healthy subjects. BMC Res Notes 2009; 2:89.

53. Taylor DD, Gerçel-Taylor C. Tumour-derived exosomes and their role in cancer-associated T-cell signalling defects. Br J Cancer 2005; 92:305-11.

54. Lodes MJ, Caraballo M, Suciu D, Munro S, Kumar A, Anderson B. Detection of cancer with serum miRNAs on an oligonucleotide microarray. PLoS One 2009; 4:e6229.

55. Hu Z, Chen X, Zhao Y, Tian T, Jin G, Shu Y, Chen $\mathrm{Y}, \mathrm{Xu} \mathrm{L}$, Zen K, Zhang C, Shen H. Serum microRNA signatures identified in a genome-wide serum microRNA expression profiling predict survival of non-small-cell lung cancer. J Clin Oncol 2010; 28:1721-6.

56. Hennessey PT, Sanford T, Choudhary A, Mydlarz WW, Brown D, Adai AT, Ochs MF, Ahrendt SA, Mambo E, Califano JA. Serum microRNA biomarkers for detection of non-small cell lung cancer. PLoS One 2012; 7:e32307.

57. Bianchi F, Nicassio F, Veronesi G, di Fiore P. Circulating microRNAs: next-generation biomarkers for early lung cancer detection. Ecancermedicalscience 2012; 6:246.

58. Shen J, Todd NW, Zhang H, Yu L, Lingxiao X, Mei Y, Guarnera M, Liao J, Chou A, Lu CL, Jiang Z, Fang H, Katz RL, Jiang F. Plasma microRNAs as potential biomarkers for non-small-cell lung cancer. Lab Invest 2011; 91:579-87.

59. Rani S, Gately K, Crown J, O'Byrne K, O'Driscoll L. Global analysis of serum microRNAs as potential biomarkers for lung adenocarcinoma. Cancer Biol Ther 2013; 14.

60. Xu T, Liu X, Han L, Shen H, Liu L, Shu Y. Up-regulation of miR-9 expression as a poor prognostic biomarker in patients with non-small cell lung cancer. Clin Transl Oncol 2013. [In Press]

61. Matsubara H, Takeuchi T, Nishikawa E, Yanagisawa K, Hayashita Y, Ebi H, Yamada H, Suzuki M, Nagino M, Nimura $Y$, Osada $H$, Takahashi $T$. Apoptosis induction by antisense oligonucleotides against miR-17-5p and miR-20a in lung cancers overexpressing miR-17-92. Oncogene 2007; 26:6099-105.

62. Tavazoie SF, Alarcón C, Oskarsson T, Padua D, Wang Q Bos PD, Gerald WL, Massagué J. Endogenous human microRNAs that suppress breast cancer metastasis. Nature 2008; 451:147-52. 